\title{
ФОРМУВАННЯ «ВІН - ВОНА» ДОМІНАНТИ ЛІРИЧНОГО ТЕКСТУ \\ (на матеріалі поезій Булата Окуджави й Сергія Жадана)
}

У статті розглянуто використання парних співположень особових займенників ВІН - ВОНА, які формують поетико-граматичну домінанту ліричного твору. Стверджується, що відсутність у тіричному тексті 3 «ВIH - ВОНА» домінантою співвідносних із займенниками субстантивів сприяє узагальненню тіричної ситуації. Наголошується, що використання y XX сторіччі родової пари особових займенників «BIH - ВОНА» в значенні 'закохані' є поетичною універсалією, яка характерна для російської й українької тірики XX-XXI століть. В окремих віршових творах вона формує поетико-граматичну домінанту, що грунтується на категорійному протиставленні жіноче - чоловіче й пов'язана з темою любові.

Ключові слова: тінгвопоетика, поетична морфологія, гендерна пара, співпозиція, особові займенники, домінанта віршового тексту, відсутність субстантива.

Skorobohatova O. The Formation of «HE-SHE» Lyric Text Dominant (a Case Study of Bulat Okudzhava's and Serhiy Zhadan's Poetry). The article deals with the use of juxtaposition of personal pronouns HE-SHE, which forms a poetic and grammatical dominant of the lyrical work. It is proven that the absence of substantivized words related to pronouns in lyrical texts with "HE - SHE" dominant contributes to the generalization of the lyrical situation. It is emphasized that the use of a generic pair of personal pronouns "HE - SHE" in the sense of "people in love" in the XX century is a poetic universal, which is characteristic of Russian and Ukrainian lyrics of the XX-XXI centuries. In some poems it forms a poetic and grammatical dominant, based on the categorical opposition of feminine and masculine and related to the theme of love. Two poems with the poetic and morphological dominant "HE - SHE" - 'people in love' have been compared, where it performs a text-forming function; it forms the grammatical basis for the unfolding of lyrical narrative and helps plot formation. Those are the poems of Bulat Okudzhava "He finally came to the house ..." and Serhiy Zhadan "They can even live in different cities ...". A comparison of the poems of Bulat Okudzhava and Serhiy Zhadan, where this dominant is used, shows that the artistic techniques and grammatical meanings in the works analyzed are different. In Okudzhava's work, those pronouns convey the ambivalent poetic sense of union and confrontation, whereas in Zhadan's poetry it has just the sense of union, which is emphasized by the use of the plural form of HE in the strong positions of the text: at the beginning and at the end of the poem. The extension of the 
pronoun line clarifies the artist's poetic picture. These observations extend our knowledge of the expressive potential of the pronoun and its poetic use. We see the prospect of work in the study and comparison of the poetic potential of the morphological categories of different Slavic languages.

Key words: lingual poetics, poetic morphology, gender pair, apposition, personal pronouns, dominant of lyric text, lack of substantive.

\section{Вступ}

Своєрідність ліричного тексту полягає в тому, що особисте, навіть інколи інтимне, набуває в ньому значущості узагальненого, такого, що притаманне кожній людині, яка думає й відчуває. Таке узагальнення в окремому ліричному творі може мати лексичну, інтертекстуальну або граматичну «підтримку», поети використовують певні мовні можливості, що дають читачеві «сигнал»: усе описане відбувається не лише з ліричним героєм, згадані відчуття й думки не одноосібні.

Один з граматичних способів ліричного узагальнення полягає у використанні особових займенників, що не мають у тексті вказівки на конкретну особу. Універсальність цього способу призвела до формування цілих корпусів текстів, що можна розглядати як окремі підвиди «Я-текстів», «Ти-текстів» або «Він-Вона-текстів». Ці терміни створені літературознавцями для розрізнення контекстів, у яких поетичний наратив ведеться від першої особи, описує або звертається до співрозмовника / читача чи описує третю особу. У «Я-текстах» займенник указує на особу автора, іменування якого не потрібне, у «Ти-текстах», що присвячені темі кохання, займенник ТИ вказує на ліричного адресата. Наші спостереження демонструють, що в східнослов'янській ліриці XX й XXI століть значна кількість «Він - Вона-текстів» не містить іменника, на який дейктично вказує займенник. У цьому разі дейктична природа займенника дає змогу віднести його до будь-кого й кожен читач може узагальнити або інтимізувати поетичний досвід автора, накладаючи його на власний. Така організація художнього твору без указівки імені й номінації персонажа детально розглянута на матеріалі прозового тексту: філологи спостерігають «стрімкий процес зникнення імен у літературі XX століття» (Васильева, 2007: 271) (переклад наш - О. С.). У сучасному віршовому дискурсі, на наш погляд, цей процес розгортають у площині «Він-Вона-текстів», але в лінгвопоетичному аспекті він до сьогодні 
не проаналізований. Актуальність дослідження пов'язана з необхідністю вивчення морфологічної будови поетичних текстів і розробки поетичної граматики як одного з векторів креативного розвитку мови, що є актуальним напрямом сучасних лінгвопоетичних студій (див.: Скоробогатова, 2018). Мета цієї статті - проаналізувати використання парних співположень особових займенників ВІН - BОНА, що формують поетико-граматичну домінанту ліричного твору (термін наш - О. С. (Скоробогатова, 2012: 373-391)). Зазначена мета передбачає розв'язання таких завдань: 1) описати особливості використання парних співположень особових займенників ВIH - BOHA як поетико-граматичної домінанти ліричного твору на прикладі поезії XIX-XX століть; 2) висвітлити специфіку вживання досліджуваної домінанти в поезіях Б. Окуджави й С. Жадана.

\section{Методи та методики дослідження}

Зміст і характер поставлених завдань зумовили застосування функційного й дистрибутивного методів, що спрямовані на дослідження функціонування морфологічних одиниць у конкретному контексті крізь призму вивчення їхнього виразного й виражального потенціалу; за допомогою інтерпретаційно-текстового аналізу схарактеризовано морфологічні способи реалізації авторської інтенції щодо створення поетичного смислу. Метод типологічного зіставного аналізу дав змогу зіставити поетичні (віршові) об’єкти, при цьому відношення до прийому морфологічного відбору розглядається як певна ознака поетичних ідіостилів.

\section{Результати та дискусії}

Уже в XIX столітті займенникова пара «ВIH - ВОНА» починає передавати значення 'закохані'. ВIH без називання на ім'я в значенні 'коханий' поступово витісняє старе фольклорне значення ВIH - 'чорт', 'нечиста сила'. (див. у Даля: «Иные не называют домового иначе, как просто “онъ” (Даль, 2005: 673)). Функція табуювання в образній поетичній мові змінюється функцією інтимізації й поетичного узагальнення. Такі займенникові пари трапляються в класичній поезії, зокрема в О. Пушкіна й Т. Шевченка. Але митці слова XIX сторіччя займенникову пару (як і одиничні займенники) використовують паралельно з номінацією ліричних персонажів на ім'я або поряд зі співвідносними повнозначними субстантивами. 
Художники XX сторіччя, насамперед в авангардній поезії, починають використовувати займенникові пари без іменника, що на нього вказує займенник ВІН або ВОНА (ОН, ОНА), наприклад: Она ушла, а он уехал / И вновь вернулися вдвоем (Д. Хармс «Пророк с Аничкова моста»).

У поемі Маяковського «Про это» займенникова співпозиція набуває напруженого еротичного змісту: Вот фон. / В постели она. Она лежит. / Он. На столе телефон. / «Он» и «она» баллада моя. Останній рядок свідчить про поетичну рефлексію - художній прийом поєднання займенників усвідомлюється автором й стає об'єктом ліричного опису. Цікаво, що в назві твору займенник это виконує функцію заміщення табуйованого слова, тобто митець використовує тут обидві займенникові потенції - і фольклорну, і новітню, табуювання й інтимізації та узагальнення.

Цю функцію назви закоханої пари в ліриці можуть виконувати займенники ТОЙ і ТА (ТОТ, ТА) в субстантивно-вказівному значенні: Синею молнией слиты уста, / Синеют вместе тот и та. / Ночами молния взлетает / Порой из ласки пары уст (В. Хлєбников «Русь, ты вся поцелуй на морозе!»). У цьому разі посилюється смисл авторського відсторонення й споглядання (про цю специфіку займенника ТОЙ (ТОТ) див.: (Ковтунова, 1986)).

У багатьох поезіях займенникове співположення слугує граматичним підгрунтям розгортання поетичного роздуму (наприклад: сентиментальна історія:/ він любить ї, а вона його. <...> Що робити з любов'ю, коли вона заходить в зеніт? (Г. Крук. «Сентиментальна історія...»)) або ліричного сюжету (он был католическим священником - / она читала Верлена /.<...> они обвенчались (Д. Арбєніна «Католический священник»)). Займенникова гендерна пара «ОН - $\mathrm{OHA»}$ передає стале на кінець XX століття значення. Ефект непередбачуваності виникає внаслідок появи третього елемента родової парадигми - займенника ОНО, наприклад: Он превращает воду в вино. / Она вино преврашает в воду, / чтобы он не надрался. Оно / превращается, но через пеньколоду. <...> Она все трезвее. / Он все хмельней. / Оно все крепче (В. Павлова «Он превращает воду в вино...»). Значення цього займенника змінне й вичитується лише з контексту (оно - вино) при сталому в сучасному поетичному дискурсі значенні чоловічо-жіночої пари 'закохані'. Поезія В. Павлової слугує зразком тексту, у якому 
сформована займенникова повнородова домінанта, основою якої $€$ поетичне значення «ВIH - BОНА» - 'закохані'.

Зіставимо дві поезії, у яких майстерно відтворена поетико-морфологічна домінанта «ВIH - BОНА» - 'закохані', що виконує текстотвірну функцію: формує граматичне підгрунтя розгортання ліричного наративу. Це поезії Булата Окуджави «Он, наконец, явился в дом...» i Сергія Жадана «Вони навіть можуть жити в різних містах...».

Розглянемо текст Окуджави:

Он, наконеи, явился в дом, где она сто лет мечтала о нем, куда он сам сто тет спешил: ведь она так решила, и он решил.

Клянусь, что это любовь была. Посмотри - ведь это ее дела. Но знаешь, хоть Бога к себе призови, все равно ничего не понять в любви.

И поздний дождв в окно стучал, и она молчала, и он молчал, и он повернулся, чтобы уйти, и она не припала кего груди.

Я клянусь, что и это любовь была, посмотри - ведь это ее дела. Но знаешь, хоть Бога к себе призови, все равно ничего не понять в любви ${ }^{1}$.

Відтворено дві ліричні ситуації. Перша (1-2 строфи) - ситуація повернення чоловіка після довгої розлуки закоханих. Перший рядок $\mathrm{OH}$, наконеи, явился в дом... має не дуже позитивне забарвлення. Лексема наконеи і дієслово явился в значенні 'прийшов' мають досить негативну контекстуальну конотацію. Але в другій строфі поет свідчить: Клянусь, что это любовь была..., - і любовна ситуація набуває ліричного змісту.

Друга ситуація (3-4 строфи) - ситуація розставання: дощ, мовчання, він іде, вона не зупиняє. І знову поет наголошує: Я клянусь, что и это любовь была..., - і закликає читача: посмотри - ведь это

1 Текст цитуємо за виданням (Окуджава, 2004: 112-113), а не за пісенним варіантом - О. С. 
ее дела. Тема любові в цій поезії наскрізна, вона поєднує різні ліричні ситуації, а іiі граматичне підгрунтя - повтор займенникової пари, який створює поетико-морфологічну домінанту.

Сергій Жадан також використовує експресію родової співпозиції, але він розширює займенниковий ланцюг, поєднуючи родові опозити він, вона із займенником у множині вони. Саме цей займенник і починає вірш, відтворюючи поетичний смисл об'єднання, сукупності:

Вони навіть можуть жити в різних містах, і в своїх розмовах не торкатися головного, але ті слова, які він ій пище в листах, вона читає так, ніби їх не було до нього.

I коли вона не отримує від нього тистів, і починає нити і рахувати втрати, вона ненавидить все, що він ій говорив, себто, ненавидить взагалі усе, щзо може згадати.

I коли він відкриває світ, ніби верстак, пристосовуючи його до любові своєї, все, що він робить, він робить щоразу так, аби вона розуміла, щзо він це робить для неї.

Тому що для нвого найгіриим з усіх терзань, миттю, коли починались усі його біди, завжди було проводжати їі на нічний вокзал, до останнього сподіваючись, щзо вона не поїде.

I тому він хоче просто бути з нею изієї зими, класти їй на подушку зібрані метеорити, і спати з нею так, як пси сплять із дітьми щьоби зігріти і щоби не розбудити.

І він говорить - хай буде так, хай буде без таємниць.

Хай буде так, - погоджується вона, рахуючи заметілі.

Мова їм потрібна лише для того, аби не наговорити дурниць.

Весело працює волинка серия в гарячому тілі.

Цей твір описує цілком радісну ліричну ситуацію душевної злуки закоханих. Останній ії рядок Весело працює волинка серия в гарячому 
тілі, у ньому лексеми весело, серие й словосполучення гаряче тіло узагальнюють любовний ліричний наратив. Це відрізняє поезію Жадана від поезії Окуджави, де не лише сам сюжет, але й наявність у останньому рядку все равно ничего не понять в любви... часток не й ні на фоні теми любові підкреслює песимістичний забарвлення всього твору.

Займенникова домінанта в поезії Жадана наскрізна, пара він-вона наявна в кожній строфі, а в першій і в останній їхню співпозицію доповнює множинна форма, створюючи рамочну композицію поетичного твору.

Сергію Жадану притаманний розгорнутий ліричний наратив, для оформлення якого може використовуватись композиційна рамка. Її фіксуємо й в інших поезіях. Іноді композиція ускладнюється, поет створює своєрідний граматичний орнамент. Зокрема поезія «Перші дні листопада» починається строфою:

Вона спить у порожній кімнаті, в чужому ліжку.

А він думає: чуже місто, чужа кімната -

як я їі тут залишу?

А закінчується строфами:

І ось він сидить, відраховуючи хвилини.

Сидить, нервує без потреби.

А вона не прокидається лише з тієї причини,

щьо боїться, прокинувшись, не побачити його коло себе.

Осінь над ними $з$ льоду й сталі.

Холодні ріки, незнайомі люди.

Найбільше вони бояться, щзо все ие триватиме далі.

Найбільше вони бояться, щьо більше нічого не буде.

Передостання строфа має родову займенникову опозицію, як і перша, а остання поєднує дійових осіб цієї ліричної розповіді за допомогою використання займенника вони. Поезія створює й залишає відчуття тривоги, бо твір написаний під час і на тлі війни, але любовна тема тут досить позитивна. Кохання й війна протиставлені в останніх рядках: Найбільще вони бояться, що все це триватиме далі (де все це осінь з льоду і сталі, холодні ріки, незнайомі люди), але Найбільше вони бояться, щзо більше нічого не буде (де все - це життя й кохання). 


\section{Висновки}

Граматичний аналіз доводить, що використання родової пари «ВIH - ВОНА» особових займенників $є$ поетичною універсалією, що характерна для російської й української лірики XX-XXI століть. Вона передає стале в поетичній мові значення 'закохані'. В окремих віршових творах уживання гендерної займенникової пари формує поетико-граматичну домінанту, яка грунтується на базовому категорійному протиставленні жіноче - чоловіче й пов'язана з темою любові. Порівняння поезій Булата Окуджави й Сергія Жадана, де відтворена ця домінанта, показує, що художні прийоми й сформовані граматичні смисли в аналізованих творах відмінні. У творі Окуджави займенникова пара передає амбівалентний поетичний смисл об'єднання - протистояння, проте в поезії Жадана - лише смисл об'єднання, який підкреслений використанням форми множини ВОНИ в сильних позиціях тексту: на початку й у кінці твору. Подовження займенникового ланцюжка уточнює поетичну картину, що ії відтворює митець.

Спостереження за створенням поетико-морфологічної домінанти «BIH - BОНА» - 'закохані' розширюють наші знання щодо виражального потенціалу займенника і його віршового використання. Перспективу роботи вбачаємо в дослідженні й зіставленні поетичного потенціалу морфологічних категорій різних слов'янських мов.

\section{ЛIТЕРАТУРА}

1. Васильева Н. В. Поэтика безымянности (по мотивам Милана Кундеры). Имя. Семантическая аура / отв. ред. Т. М. Николаева. Москва: Языки славянских культур, 2007. С. 271-288. 2. Даль В. И. Толковый словарь живого великорусского языка: в 4х т. Т. ІІ. ИО. Москва: Русский язык. Медиа, 2005. 779 с. 3. Ковтунова И. И. Поэтический синтаксис. Москва: Наука, 1986. 206 с. 4. Окуджава Б. Ш. Лирика и проза. Екатеринбург: УФактория, 2004. 672 с. 5. Скоробогатова Е. А. Грамматические значения и поэтические смыслы: поэтический потенциал русской грамматики (морфологические категории и лексико-грамматические разряды имени): моногр. Харьков: HTMT, 2012. 480 с. 6. Скоробогатова Е.А. Поэтическая морфология как направление лингвопоэтики и лингвокреативная практика филологического эксперимента. $P y c$ ская Филология. Вестн. Харьк. наи. пед. ун-та имени Г. С. Сковороды. 2018. № 4 (66). C. 3-10.

\section{REFERENCES}

1. Vasil'yeva, N. V. (2007). Poetika bezymyannosti (po motivam Milana Kundery) [Poetics of Anonymity (based on Milan Kundera)]. Imya. Semanticheskaya aura - Name. Semantic Aura, (pp. 271-288). Moskva: Yazyki slavyanskikh kul'tur [in Russian]. 2. Dal', V. I. 
(2005). Tolkovyy slovar' zhivogo velikorusskogo yazyka [Explanatory Dictionary of the live great Russian Language]. (Vol.2). Moskva: Russkiy yazyk. Media [in Russian]. 3. Kovtunova, I. I. (1986). Poeticheskiy Sintaksis [Poetical Syntax]. Moskva: Nauka [in Russian]. 4. Okudzhava, B. Sh. (2004). Lirika i proza [Lyrics and Prose]. Yekaterinburg: U-Faktoriya [in Russian]. 5. Skorobogatova, O. O. (2012). Grammaticheskiye znacheniya i poeticheskiye smysly: poeticheskiy potentsial Russkoy grammatiki (morfologicheskiye kategorii $i$ leksikogrammaticheskiye razryady imeni) [Grammatical Meanings and Poetical Senses: Poetical Potential of Russian Grammar (Morphological Categories and Lexico-grammatical Classes of Noun)]. Kharkov: NTMT [in Russian]. 6. Skorobogatova, O. O. (2018). Poeticheskaya morfologiya kak napravleniye lingvopoetiki i lingvokreativnaya praktika filologicheskogo eksperimenta [Poetic Morphology as a Direction of Linguo-poetics and Linguo-creative Practice of Philological Experiment]. Russkaya Filologiya. Vestnik Khar'kovskogo natsional'nogo pedagogicheskogo universiteta imeni G.S. Skovorody - Russian Philology. Bulletin of the Kharkov National Pedagogical University named after G. S. Skovoroda, 4(66), 3-10 [in Russian].

Скоробогатова Олена Олександрівна - доктор філологічних наук, доцент, завідувач кафедри слов'янських мов, Харківський національний педагогічний університет імені Г. С. Сковороди; вул. Валентинівська, 2, м. Харків, 61168, Україна.

Tel. 050-902-72-91

E-mail: skorobogatova.elena@gmail.com

https://orcid.org/0000-0003-0214-1889

Skorobohatova Olena - Doctor of Philology, Associate Professor, Head of the Slavonic Languages Department, H. S. Skovoroda Kharkiv National Pedagogical University; Valentynivska Str. 2, Kharkiv, 61168, Ukraine. 